\title{
Morphology and Distribution of Synapses Onto a Type of Large Field Ganglion Cell in the Retina of the Goldfish
}

\author{
PETER F. HITCHCOCK \\ Departments of Ophthalmology and Anatomy and Cell Biology, W.K. Kellogg Eye Center, \\ University of Michigan, Ann Arbor, Michigan 48105
}

\begin{abstract}
The morphology and dendritic distribution of terminals that synapse onto a type of large-field ganglion cell in the retina of the goldfish are described. Electron microscopy was combined with retrograde labelling of cells with horseradish peroxidase (HRP). Synapses from both amacrine (four types) and bipolar cells contacted the dendrites (all orders) of these cells. In contrast to a recent report describing the synaptic organization of large-field ganglion cells in the catfish (Sakai et al., '86), the synapses were relatively evenly distributed throughout the dendritic arbor, not clustered at discrete sites, and no presynaptic specializations were seen in the dendrites of the ganglion cells.
\end{abstract}

Key words: horseradish peroxidase, electron microscopy, inner plexiform layer, dendrites

Ganglion cells in the retina receive synaptic inputs from two distinct classes of cells, whose presynaptic terminals are identifiable. Amacrine cells form conventional synapses, like those seen elsewhere in the brain, and bipolar cells form ribbon synapses (Dowling and Boycott, '66). Recently, Sakai et al. ('86) reported two novel findings concerning the synaptic connections of large-field ganglion cells in the catfish. First, the synaptic inputs onto these cells were clustered at regularly spaced sites on the dendritic arbor, and second, at these sites the dendrites formed presynaptic, chemical synapses onto other processes. These results suggest that identifying ganglion cell dendrites by routine EM may be problematic, and further study of the synaptic connections of ganglion cells is needed.

The morphology and the dendritic distribution of terminals that synapsed onto a type of large-field ganglion cell (Type 1.2; see Hitchcock and Easter, '86) in the retina of the goldfish were determined. The dendrites of this cell stratify in the outermost sublamina of the inner plexiform layer (IPL), and presumably give an off-center excitatory response to light (Famiglietti et al., '77). The dendritic growth of Type 1.2 cells has been described as well (Hitchcock and Easter, '86).

The Type 1.2 ganglion cells received contacts from ribbon terminals and four distinct forms of conventional terminals. These synapses were relatively dispersed throughout the dendritic arbor, and there was no evidence that the dendrites of the ganglion cells studied here were presynaptic to other processes. Some of these data have been presented in an abstract (Hitchcock, '87).

\section{MATERIALS AND METHODS}

Ganglion cells were retrogradely labelled with HRP as described by Hitchcock and Easter ('86). Briefly, each animal (3-4-inch standard length) was anesthetized in tricaine methanesulfonate (MS-222), the orbit was opened exposing the optic nerve, and a small incision was made in the dura with a 24-gauge hypodermic needle. A pledget of gelfoam soaked in $30 \%$ HRP (ICN Immunobiological) in $2 \%$ dimethylsulfoxide was placed on the nerve, and the orbit was sealed with cyanoacrylate glue. After survival times of 2-4 days, the animals were dark-adapted for 1 or more hours, the eyes enucleated, and the retinas isolated in $0.08 \mathrm{M}$ phosphate buffer ( $\mathrm{pH} 7.2$ ). Each retina was mounted, photoreceptor side down, onto a glass slide, and a nylon mesh was placed on top to secure it. The retina was covered with a fixative while on the slide for (approximately) 5 minutes, then removed from the slide and fixed free-floating on a shaker table for 1 hour. The initial fixation on the slide served to

Accepted December 26, 1988.

Address reprint requests to Peter F. Hitchcock, Department of Ophthalmology, The University of Michigan, W.K. Kellogg Eye Center, 1000 Wall Street, Ann Arbor, MI 48105. 
keep the retina flat during the subsequent steps. The fixative was cold $2.5 \%$ glutaraldehyde $/ 2.0 \%$ paraformaldehyde in $0.08 \mathrm{M}$ Sorensen's phosphate buffer, $\mathrm{pH}$ 7.0. After fixation the retinas were rinsed for 30 minutes in buffer and processed for HRP histochemistry according to the Adams ('77) protocol using 3-3'-diaminobenzidine. These procedures produced good fixation for electron microscopy and dendrites extensively filled with the HRP reaction product (e.g., see Fig. 6A,B). Following the HRP reaction the retinas were remounted, photoreceptor side down, onto glass slides and coverslipped with phosphate-buffered glycerine (9 parts buffer: 1 part glycerine).

The goal of the labelling technique was to fill only a few isolated cells with HRP; this occurred about half of the time. (No isolated cells were found on the other occasions.) Cells well filled with HRP, of the appropriate type (Type 1.2; see Hitchcock and Easter, '86), were photographed and traced at 1,000X magnification using a light microscope and a drawing tube. Small blocks of tissue, each containing a single filled cell, were cut out of the retina, rinsed in buffer, post fixed in $0.5 \%$ osmium tetroxide in $0.1 \mathrm{M}$ phosphate buffer, $\mathrm{pH} 7.2$, for 1 hour at room temperature, and stained en bloc in $2 \%$ uranyl acetate in $0.05 \mathrm{M}$ maleate buffer, $\mathrm{pH}$ 6.0 , overnight in a refrigerator. Each block was then dehydrated in alcohols, and embedded in Polybed 812 between two plastic coverslips. The dendritic arbor of the cell and the outline of the block were then traced by using a drawing tube. These drawings were used to orient and trim the blocks for thin sectioning. The cells could be visualized in the osmicated blocks if the illumination of the light microscope was maximum and the field aperture almost closed. The blocks were then removed from between the coverslips and recast in the cap-end of a Beem capsule.

One-half-micron-thick sections were cut tangential to the retinal layers, and the dendritic arbor of the HRP-filled cell, until the outer one-third of the IPL was reached, then serial thin sections (gold interference color) were collected on onehole, formvar-coated grids. The dendritic arbors of the cells were generally contained within about 150 thin sections. On average less than $5 \%$ of the sections were lost during sectioning. Sections were stained with Reynold's lead citrate.

With an electron microscope (EM: Philips 300 or 400 ) a low-magnification photomontage of every fifth thin-section through the dendritic arbor was produced. A 1 in 5 series was chosen because individual synapses would not appear in more than one photomontage and, since the diameter of the dendrites is generally greater than $0.5 \mu \mathrm{m}$, every HRP-filled process would be inspected at least once. Using the photomontages as guides, the sections were systematically scanned at 3,500 $\times$ magnification, and when an HRP-filled dendrite was encountered it was identified on the photomontage and inspected for the presence of synapses at $12,500 \times$ magnification. The type of synapse encountered was registered on the photomontage at the site where it synapsed onto the HRP-filled dendrite. Selected synapses were photographed and printed at a final magnification of $32,000-37,000$. Using the collection of photomontages the dendritic position of each synapse was determined and registered at its equivalent position on the tracing of the cell made with the light microscope. Positioning synapses on the proximal dendrites was unambiguous since the dendrites were large, their contours in thin sections matched that seen at the light level, and branch points and the location at which the dendrites joined the soma served as constant landmarks (see Fig. 6A,B). The locations of synapses onto the distal dendrites were determined by reconstructing the dendrites by tracing them (and their synaptic inputs) from each low-magnification montage onto a sheet of tracing paper as an intermediate step, then registering the synapses onto their equivalent positions on the light microscopic tracings of the cell.

\section{RESULTS Terminal morphology}

The results from six cells are described below. All were of the Type 1.2 originally described by Hitchcock and Easter ('86). All are from the region of the retina where the ganglion cells have mature dendritic arbors (Hitchcock and Easter, '86). The Type 1.2 cell is characterized by a large soma, large dendritic field, thick proximal dendrites, and a dendritic arbor that is unistratified within the outermost layer of the inner plexiform layer (outer sublamina a). This latter feature was a distinct advantage in that relatively few thin sections needed to be cut to include the entire dendritic arbor, and much of the arbor was contained within each thin section. Three of the cells had somata that were "displaced" into either the inner nuclear layer, or into the IPL. The dendritic fields of Type 1.2 cells form territorial domains, so as to completely cover the retina with their processes (Hitchcock, '87), and removal of any one, whatever the location of its soma, results in an obvious gap (Hitchcock, unpublished observations; Vaney, '87). For this reason, cells with somata not in the ganglion cell layer were not regarded as separate types.

HRP-filled processes were identified by their electron density, dark mitochondria, and the flocculent HRP reaction product that decorated the microtubules (Figs. 1-5; Marshak et al., '88). Also, the dendritic cytoplasm appeared to be somewhat disrupted, containing vacuoles and regions vacant of cytoplasm, perhaps a result of the HRP reaction.

Conventional synapses were identified at sites where the pre- and postsynaptic membranes were parallel, more widely spaced than other apposed membranes, and (at least) several vesicles were in close proximity to the presynaptic membrane (see Dubin, '70). Ribbon synapses were identified by the presence of the membrane specializations described above, and the presence of a ribbon organelle surrounded by a halo of synaptic vesicles. It is assumed that conventional and ribbon synapses arise from amacrine and bipolar cells, respectively (Dowling and Boycott, '66; Witkovsky and Dowling, '69), and they are referred to as such. Figures 1 through 5 illustrate examples of the morphology of the terminals that synapsed on the Type 1.2 cell.

Four types of terminals from amacrine cells (Table 1) were distinguished based upon their electron density, density of synaptic vesicles, and types of intracellular organelles. Figure 1 illustrates the most commonly encountered terminal that contacted an HRP-filled dendrite. These terminals were pleomorphic, usually contained mitochondria, had a variable density of synaptic vesicles, and were relatively electron lucent. Their average diameter was $1.2 \mu \mathrm{m}$ with a range of $0.5-2.2 \mu \mathrm{m}(n=25)$. Figure 2 illustrates the second most frequently observed terminal. They were relatively electron dense (similar in electron density to the bipolar terminals; see below), had a high density of synaptic vesicles, and only rarely contained mitochondria. Their average diameter was $1.1 \mu \mathrm{m}$ with a range of $0.5-1.5 \mu \mathrm{m}(\mathrm{n}=25)$. Since these terminals had an electron density and density of 


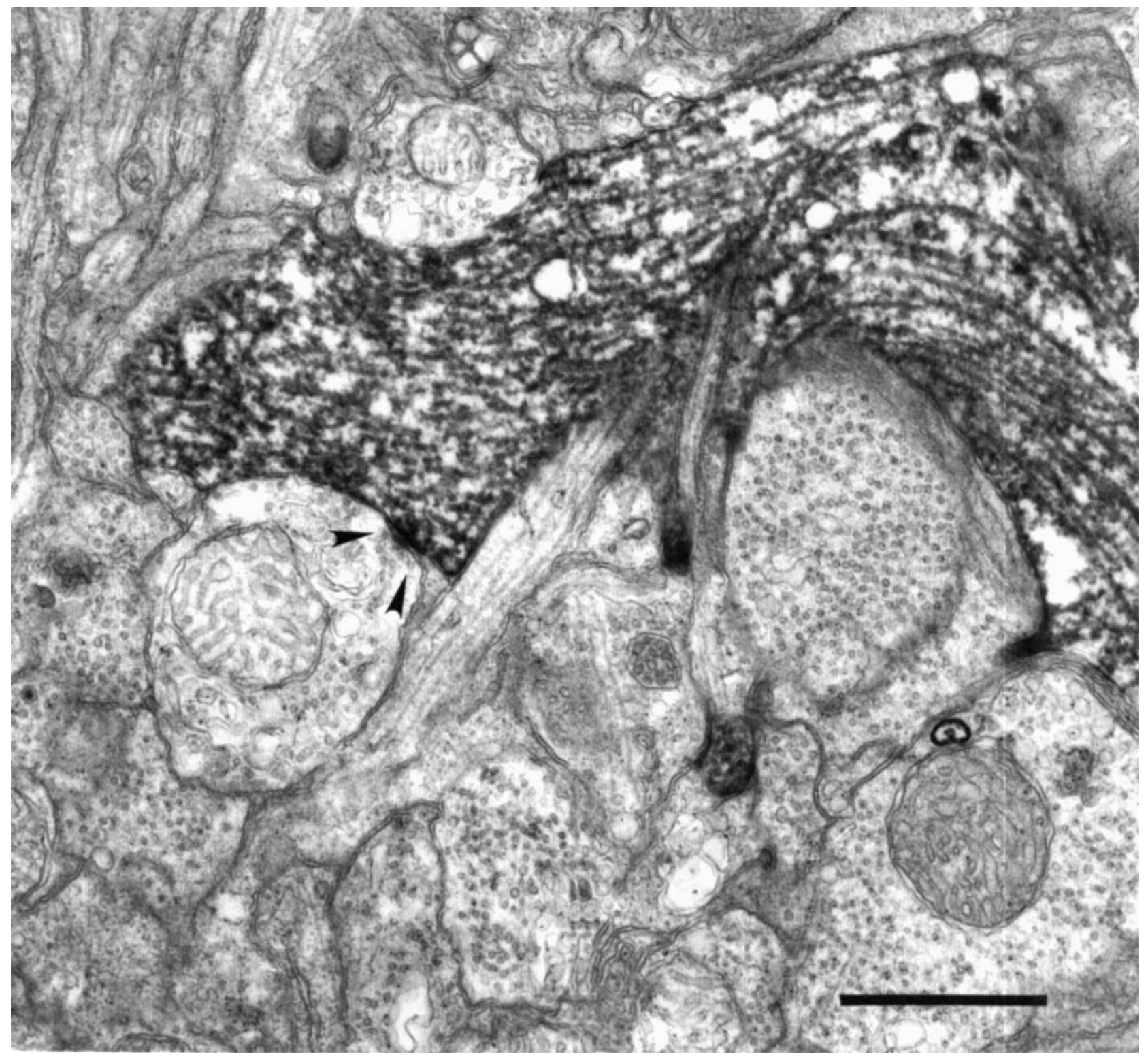

Fig. 1. EM photomicrograph of a synapse from an amacrine cell onto an HRP-filled dendrite. This was the most commonly seen terminal that contacted the Type 1.2 cell. It was characterized by its relative electron lucency, a variable density of synaptic vesicles, variable shape, and content of mitochondria. Arrowheads mark the region of the presynaptic specializations. Note the flocculent appearance of the HRP reaction product and the relatively disrupted dendritic cytoplasm (see also Figs. 2-5). Scale bar $=1 \mu \mathrm{m}$.

synaptic vesicles similar to the bipolar terminals (see below), it was possible that these were small bipolar terminals in which the synaptic ribbons were out of the plane of the section. However, nine of these terminals were inspected in serial sections, and none contained a ribbon organelle. These terminals were not traced to their cells of origin, and it remains possible that they were bipolar terminals that did not contain synaptic ribbons (see Wong-Riley, '74). Figure 3 illustrates an example of a terminal that contained densecored vesicles. Although terminals containing dense-cored vesicles were frequently seen, only 10 were observed to synapse onto the cells studied here. Figure 4 illustrates an example of the least frequently encountered terminal that contacted an HRP-filled dendrite. These synapses were in large, electron lucent, microtubule-rich processes, which were oriented tangentially within the IPL. similar to the HRP-flled dendrites. These processes were often apposed to the HRP-filled dendrites for several microns, and formed discrete en passant synapses onto them.

Figure 5 illustrates the morphology of the bipolar terminals that synapsed onto the Type 1.2 cell. These terminals were relatively electron dense and contained densly packed 


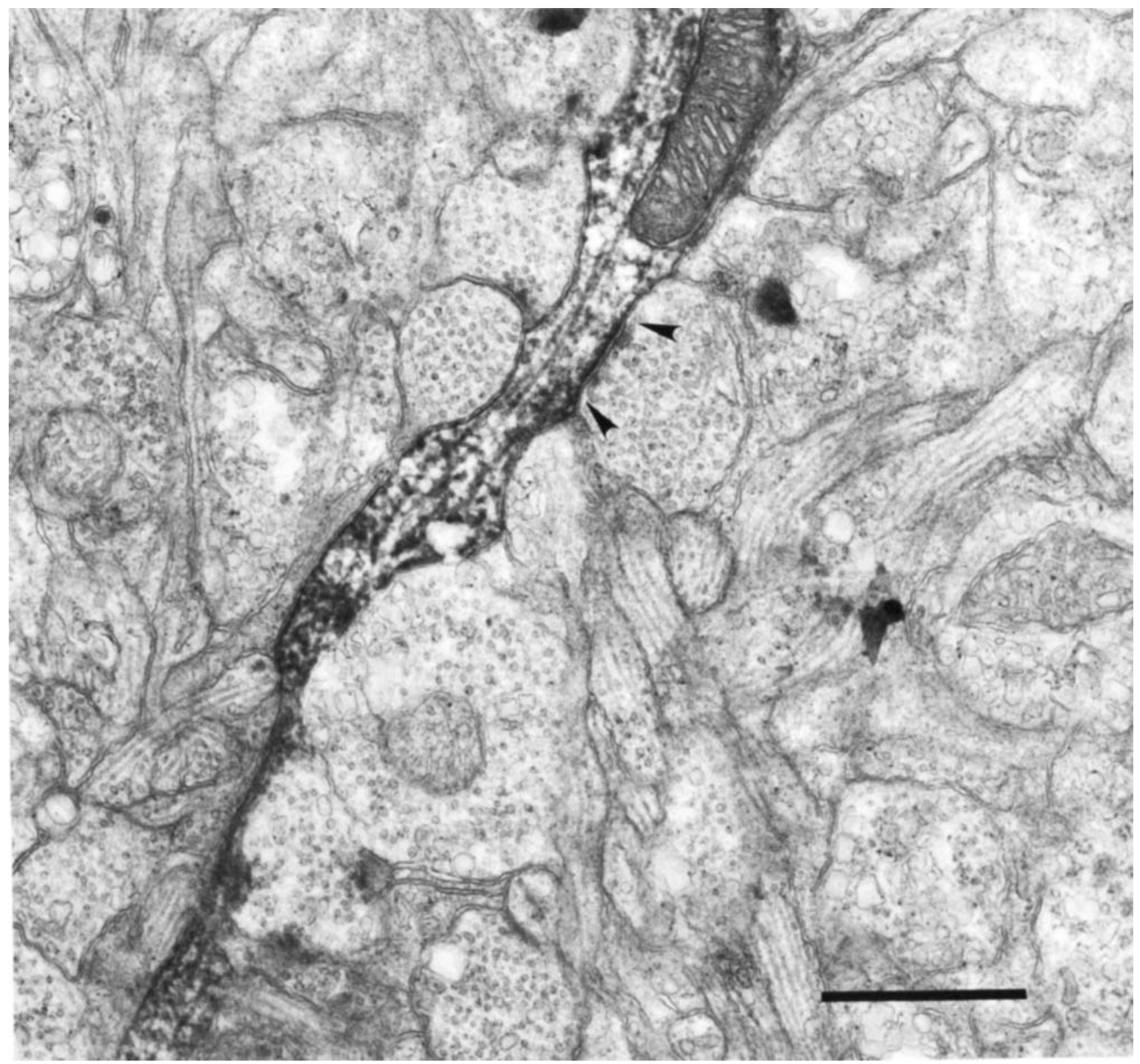

Fig. 2. EM photomicrograph of a synapse from an amacrine cell onto an HRP-filled dendrite. This type of terminal was the second most commonly encountered. It was characterized by its relatively high electron density, high density of synaptic vesicles, and relative lack of mitochondria (see also Fig. 5). Arrowheads mark the region of the presynaptic specializations. Scale bar $=1 \mu \mathrm{m}$.

synaptic vesicles. Both large and small terminals synapsed onto the HRP-filled profiles (see Fig. 5); however, synapses from large terminals were seen more frequently. A common feature of the large terminals was the close apposition of the pre- and postsynaptic membranes (Fig. 5; also see Figs. $9 \mathrm{~A}, \mathrm{~B})$. In general, the HRP-filled dendrites were one of a pair of postsynaptic processes; the other process generally contained synaptic vesicles, presumably belonging to an amacrine cell. Infrequently, within the large bipolar terminals, two ribbon synapses would contact an HRP-filled dendrite at different locations, separated by the width of the terminal. No synapses were observed at which both postsy- naptic processes were filled with HRP. The number and relative frequency of each type of terminal that synapsed onto the cells studied here is illustrated in Table 1.

\section{Dendritic distribution of synapses}

Figure 6a illustrates a light micrograph of an HRP-filled, Type 1.2 cell in the wholemount, and Figure $6 \mathrm{~B}$ illustrates an EM photomicrograph of a thin section through the dendritic arbor of this cell. Figure 7 illustrates a light microscopic drawing of the cell illustrated in Figure 6, and the location of the synapses from amacrine and bipolar cell ter- 


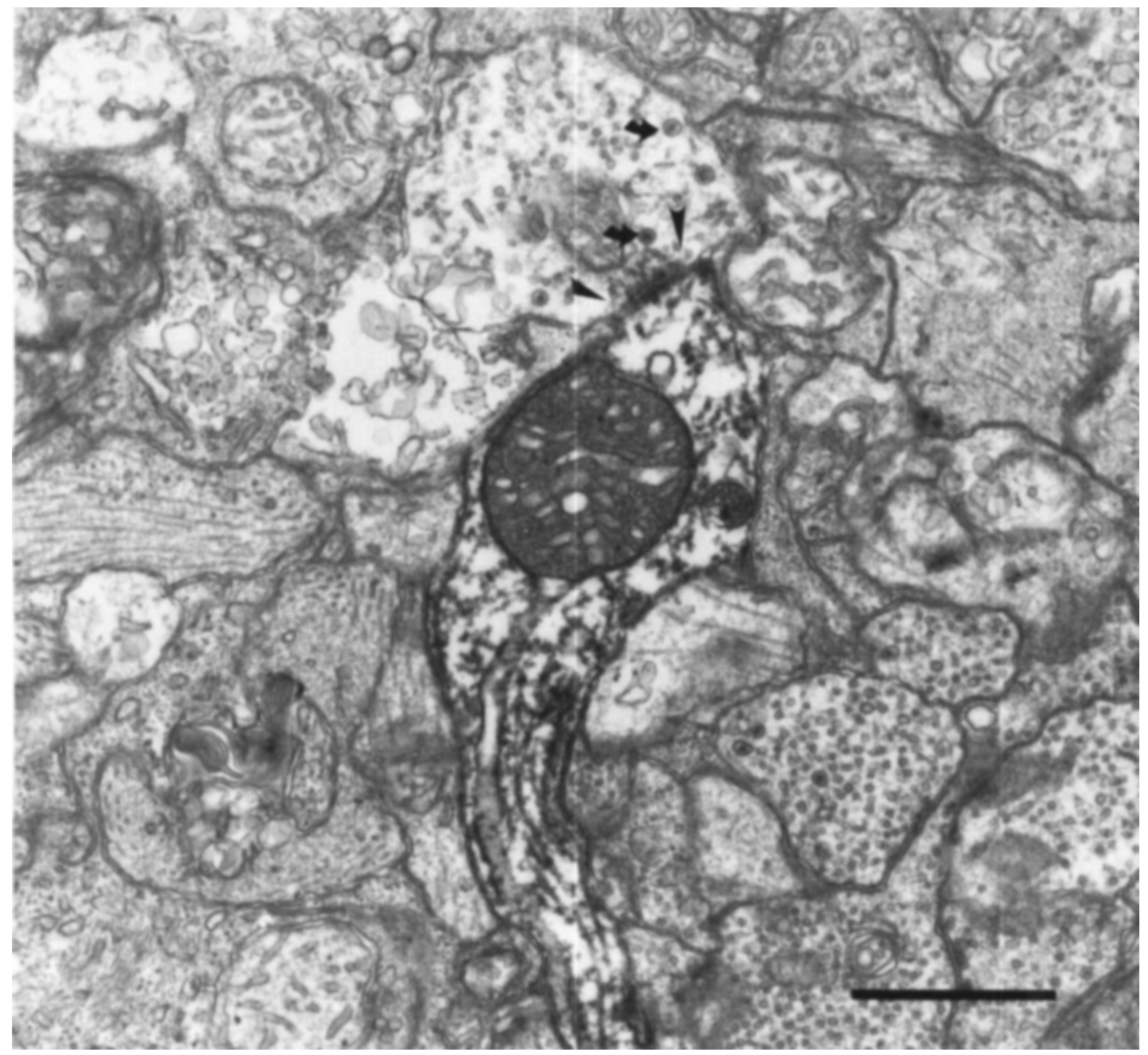

Fig. 3. EM photomicrograph of a synapse from an amacrine cell onto an HRP-filled dendrite. This type of terminal only rarely synapsed onto the cells studied here. It was characterized by the presence of densecored vesicles (marked with arrows). Arrowheads mark the region of the presynaptic specialization. Scale bar $-1 \mu \mathrm{m}$.

minals that contacted it. Figure 8 illustrates another cell and the location of its synaptic inputs. Some of the cells studied here had a few beaded dendrites. Rather than being sites of synaptic contact, it was discovered that the swellings were vacant of cytoplasm and organelles, and it is assumed that these dendrites were degenerating at the time of fixation.

Inspection of Figures 7 and 8 shows that numerous terminals from amacrine and bipolar cells synapsed onto the dendrites of each of the ganglion cells. Both types of cells synapsed onto all orders of dendrite, as well as onto den- dritic appendages. The dendritic location of the three minor types of conventional synapses (Table 1) was variable. In general, the electron-dense terminals were found throughout the arbor, whereas the terminals containing dense-cored vesicles and the en passant synapses were found on distal dendrites. None of these synapses, however, were systematically located at particular sites in the arbor, e.g., branch points. For the cells illustrated in Figures 7 and 8, no bipolar synapses were seen on the primary dendrites; however, the primary dendrites of other Type 1.2 cells received bipolar synapses. No synapses were seen to contact the somata, or 


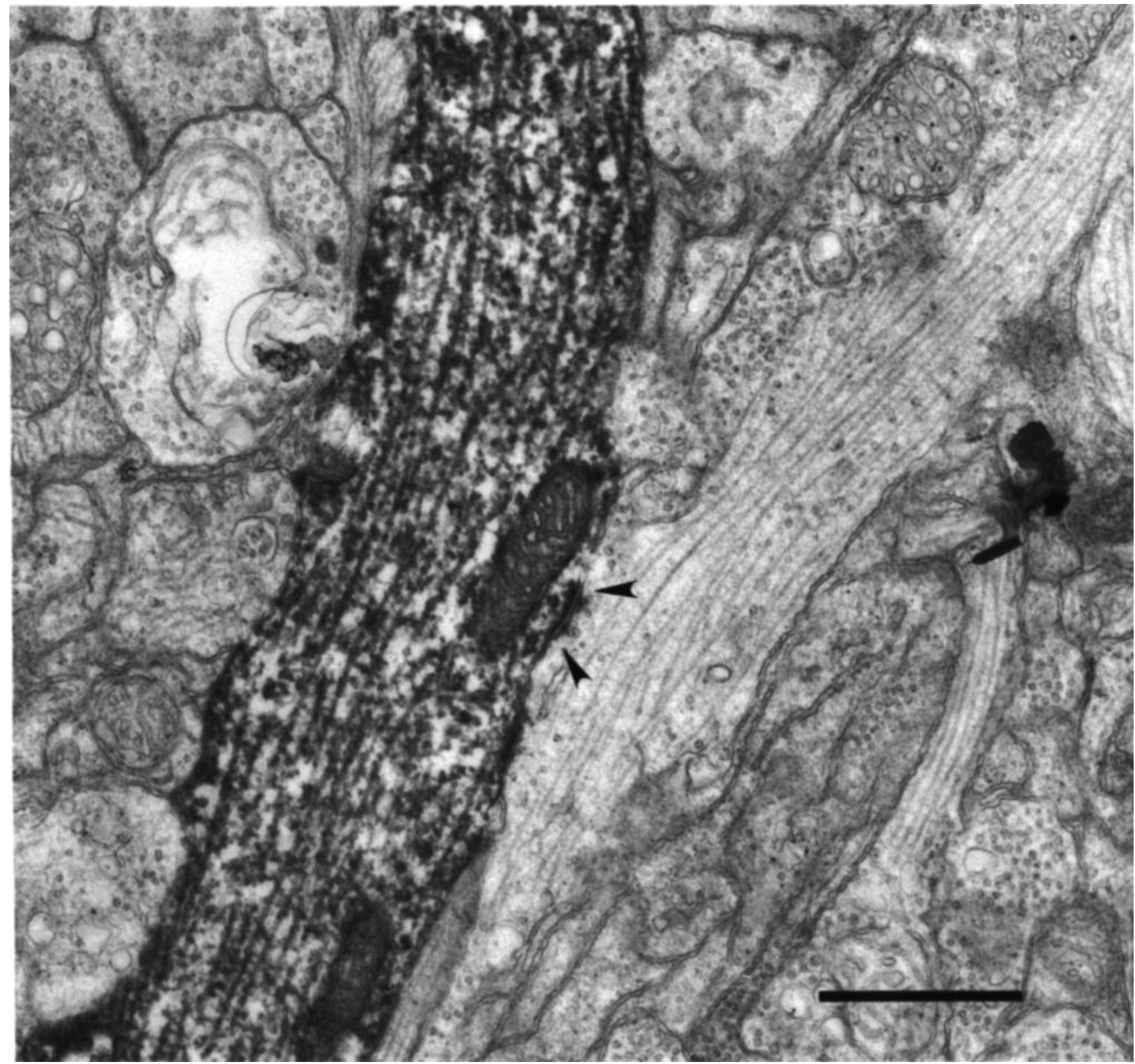

Fig. 4. EM photomicrograph of a synapse from an amacrine cell onto an HRP.filled dendrite. These synapses, in large, electron lucent, microtubule-rich processes made en passant contacts, and were infrequently seen. Arrowheads mark the region of the presynaptic specialization. Scale bar $=1 \mu \mathrm{m}$.

regions of the proximal dendrites as they descended from the ganglion cell layer into the distal IPL (see also West and Dowling, '72). The synapse from an amacrine cell that appears to end on the perikaryon in Figure 8 synapsed onto the primary dendrite lying below the soma. Figures 7 and 8 also show that synapses from the amacrine and bipolar cells are both intermixed and distributed relatively evenly throughout the dendritic arbor.

Synapses appeared to be more numerous on the proximal dendrites. This probably reflects two factors. First the sampling methods used here were more likely to detect synapses on thick dendrites, which, in contrast to thin ones, appear in many sections, and second, thin dendrites, due to their smaller surface area, presumably received fewer synapses per unit length than thick ones. As a result, those thin dendrites distally located in the arbor appear relatively synapse free. No differences were seen in the types and distribution of synaptic inputs onto cells whose somata were located in the ganglion cell layer or displaced into the inner nuclear layer. On average, 104 amacrine and 36 bipolar synapses were observed to contact each cell. Given that conventional synapses and the ribbon organelles average about $0.2 \mu \mathrm{m}$ in 


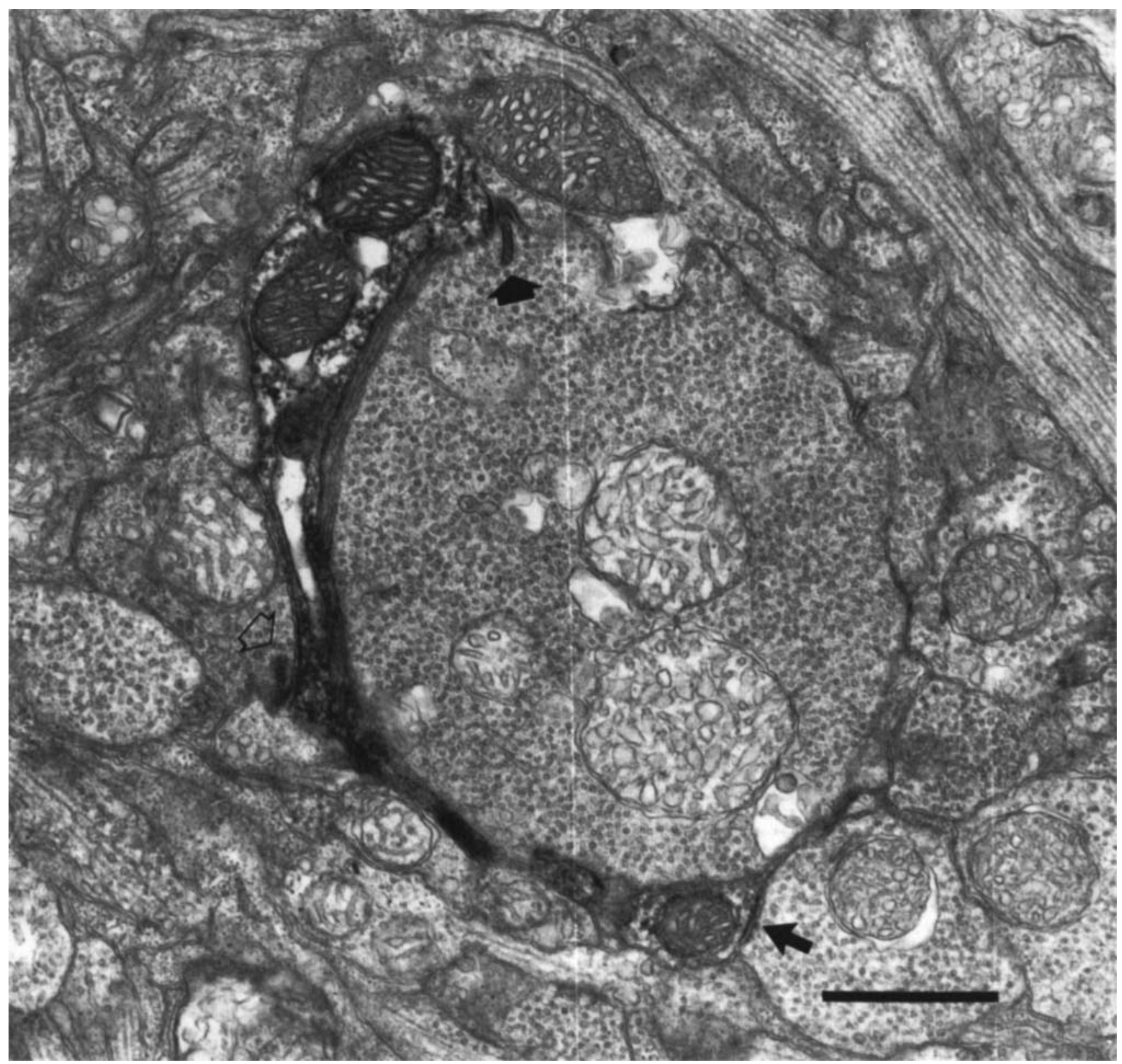

Fig. 5. EM photomicrograph of a synapse from a bipolar cell onto an HRP-filled dendrite. The bipolar terminals were in general large, densely filled with vesicles, and relatively electron dense. The small, filled arrow marks the ribbon organelle. The open arrow indicates a second synapse from a bipolar cell, in a small terminal, ending on the HRP- filled dendrite. The large arrow indicates the location of a conventional synapse contacting the HRP-filled dendrite. This terminal was relatively electron dense and contained a high density of vesicles, similar to that described in the Results (see also Fig. 2). Scale bar $=1 \mu \mathrm{m}$. length (Hitchcock, unpublished observations), each should appear in 2-2.5 consecutive sections (assuming that the sections are approximately $0.09 \mu \mathrm{m}$ thick). Since every fifth section through each cell was inspected for synapses, Type 1.2 cells in a $3-4$ inch goldfish should receive roughly 200 250 synapses from amacrine cells and 70-100 synapses from bipolar cells.

Figure 9A,B illustrates an artifact that was consistently seen in this study; electron-dense processes that were not labelled with HRP. Figure 9A shows a low-magnification EM photomicrograph of several electron dense and HRPfilled processes. Figure $9 \mathrm{~B}$ is a high-magnification photomicrograph of the area outlined in Figure 9A. These cells were not seen in the retinal wholemounts, even though they had an electron density that was sometimes equal to the HRP. filled ones. The presence of these cells was initially misleading; however, they had an obviously different appearance from those cells filled with HRP (see above). 'They had uni- 

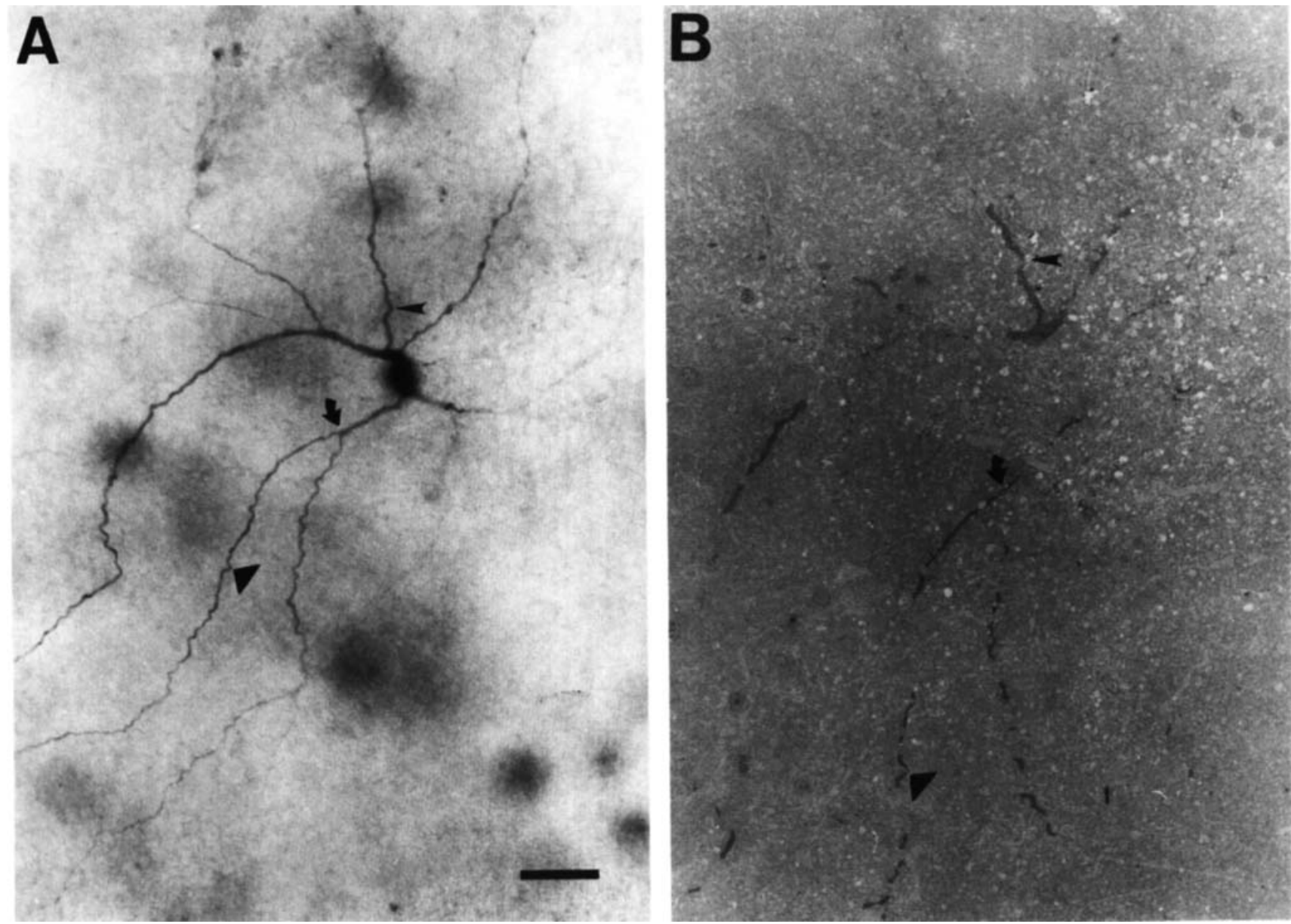

Fig. 6. A. Light photomicrograph of an HRP-filled, Type 1.2 ganglion cell in a retinal wholemount. B. Low-magnification EM photomicrograph through the proximal dendrites of the cell illustrated in A. Similar symbols indicate common locations in the dendritic arbor seen at the light and EM levels, respectively. Scale bar $=50 \mu \mathrm{m}$ and $18 \mu \mathrm{m}$ in A and B, respectively.

formly electron-dense cytoplasm, electron lucent mitochondria, and an orderly arrangement of their microtubules. Similar electron-dense profiles have not been seen in routine EM preparations (Hitchcock, unpublished observations). These cells did not contact the HRP-filled ganglion cells studied here, and Marshak et al. ('88), using similar histological techniques, did not observe any transneuronal labelling of neurons presynaptic to HRP-filled ganglion cells, thus suggesting that the electron-dense cells illustrated in Figure 9 were not diffusely filled with the HRP reaction product. However, treatment of an unlabelled retina according to the Adams ('77) protocol with 3-3'diaminobenzidine (see Methods) did not stain any of these cells. What type of cell these are and the reason for their appearance remain in question.

\section{DISCUSSION}

The Type 1.2 cell received inputs from bioplar cells and four different forms of amacrine cells. An inference is that the different conventional terminals were from different
TABLE 1. Total and Relative Numbers of Synapses From Bipolar and Amacrine Cells That Contacted the Ganglion Cells Studied Here

\begin{tabular}{llc} 
& Total & Percent \\
\hline Bipolar & 215 & 25 \\
Annacrine & 626 & 75 \\
$($ EL) & $(558)^{\mathrm{b}}$ & $(89)$ \\
$(\mathrm{ED})^{\mathrm{c}}$ & $(51)$ & $(8.1)$ \\
(DCV) $^{\mathrm{d}}$ & $(10)$ & $(1.6)$ \\
(EnP) $^{\mathrm{d}}$ & $(7)$ & $(1.1)$ \\
\hline
\end{tabular}

${ }^{a}$ Electron lucent, pleomorphic terminals.

bValues in parentheses currespond to the population of amacrine cell synapses only. Flectron-dense terminals.

Electron-dense terminals.
dTerminals that contained dense cored vesicles.

"Terminals that containec

types of amacrine cells. No attempt was made to confirm this, and the possibility remains that more or fewer than four types of amacrine cells contact a given Type 1.2 cell. The neurochemical identity of these terminals is also unknown (however, see Muller and Marc, '85), with the exception that those terminals that contained dense-cored vesicles were probably peptidergic (Marshak et al., '84; Pickel, 


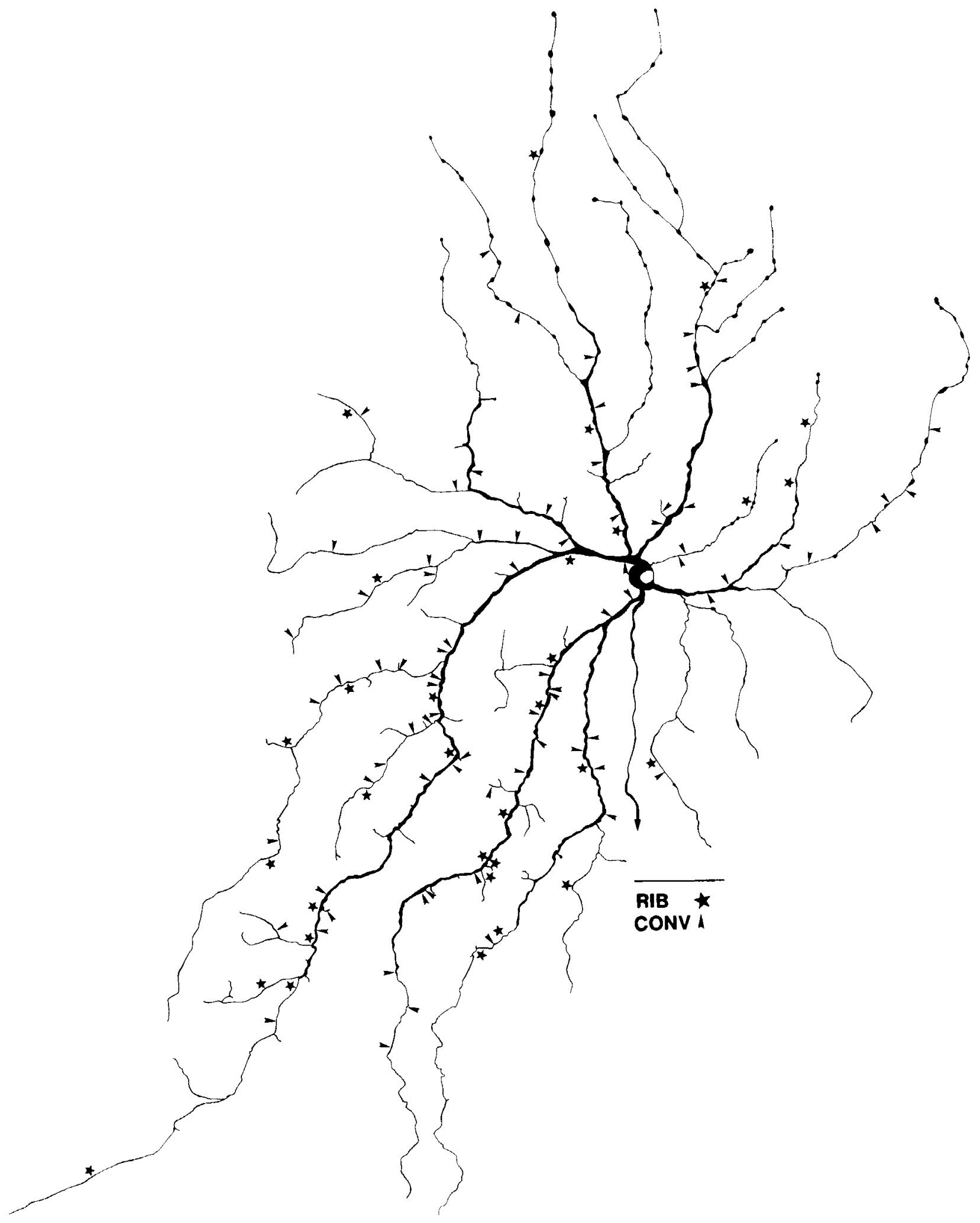

Fig. 7. Light microscopic tracing of the HRP-filled ganglion cell illustrated in Figure 6. Arrowheads and stars indicate the locations of conventional (amacrine cell) and ribbon (bipolar cell) synapses, respectively. The downward pointing process tipped with an arrowhead is the axon. Scale bar $=50 \mu \mathrm{m}$. 


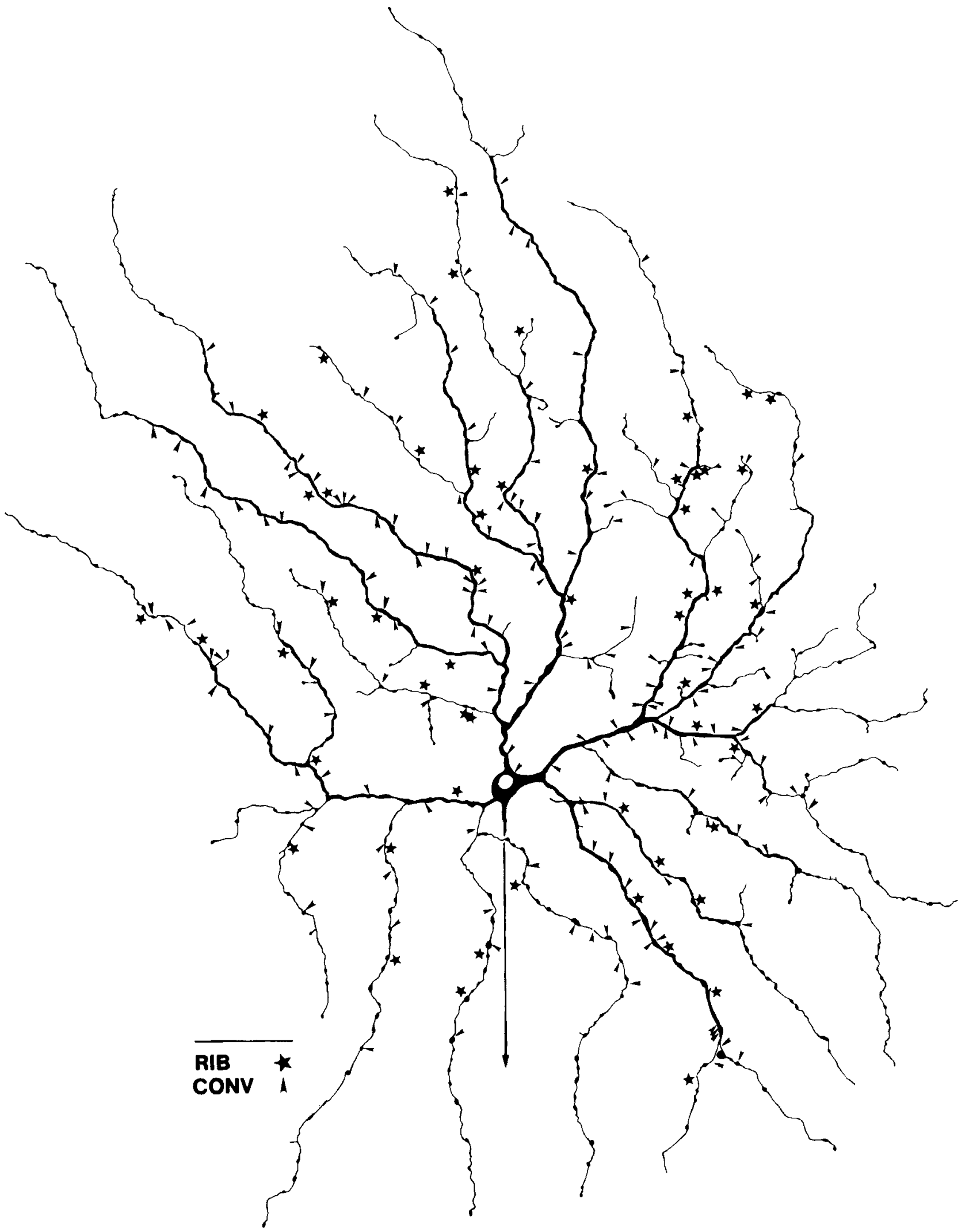

Fig. 8. Light microscopic tracing of an HRP-filled ganglion cell showing the locations of conventional (amacrine cell) and ribbon (bipolar cell) synapses, respectively. The downward pointing process tipped with an arrowhead is the axon. The arrowhead pointing toward the soma represents a conventional synapse that was located on a dendrite lying below the soma within the distal most layer of the IPL. Scale bar $=50 \mu \mathrm{m}$. 


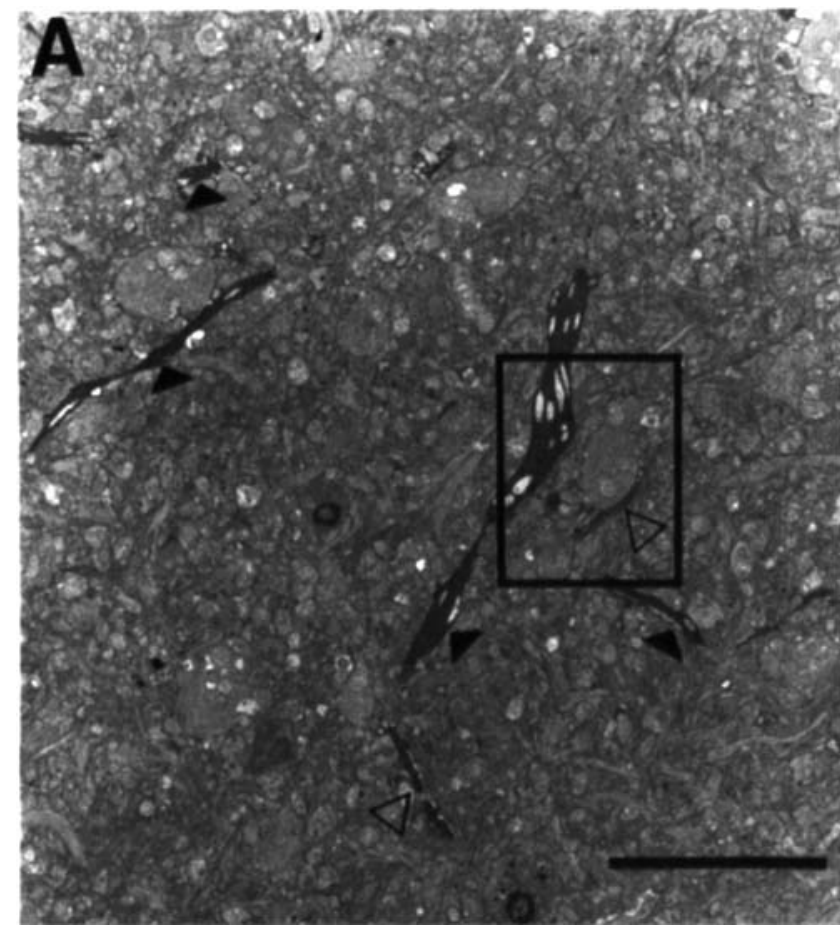

Fig. 9. A. Low-magnification EM photomicrograph showing several electron-dense processes (closed arrowheads), not filled with HRP, and two HRP-filled dendrites (open arrowheads). The region enclosed within the square is illustrated at higher magnification in B. B. Highmagnification EM photomicrograph illustrating the morphology of the

'85; Yazulla et al., '84, '85). In contrast to the terminals from amacrine cells, the bipolar terminals were more uniform in their appearance. They were generally large, relatively electron dense, contained several mitochondria, had a high density of vesicles, and formed dyadic synapses onto an HRPfilled dendrite and another unlabelled process. By virtue of the distal location within the IPL of the dendrites of the Type 1.2 cell, the bipolar terminals that contacted them were probably from one of the type "a" bipolar cells described by Ishida et al. ('80).

Assuming that both types of synapses were sampled similarly, these data suggest that the ratio of amacrine to bipolar cell input onto these cells was about 3:1 (Table 1). Recently, Marshak et al. ('88) quantified the proportion of synaptic inputs onto the dendrites of ganglion cells in the goldfish. They found that the overall ratio of amacrine to bipolar inputs onto ganglion cells was about 16:1. Together, these data suggest that the ratio of amacrine to bipolar cell inputs onto individual ganglion cells varies widely (see also West and Dowling, ' 72 ).

Synapses from both amacrine and bipolar cells were distributed relatively evenly throughout the dendritic arbors of the Type 1.2 cells (see Results). Using similar techniques, Freed and Sterling ('88) showed that the bipolar synapses onto large-field (alpha) ganglion cells in the cat were clustered, but these clusters were derived from individual terminals that, on average, made multiple contacts. The terminals themselves were evenly distributed throughout the dendritic arbor. Synapses from amacrine cells onto alpha cells were dispersed throughout the dendritic arbor and

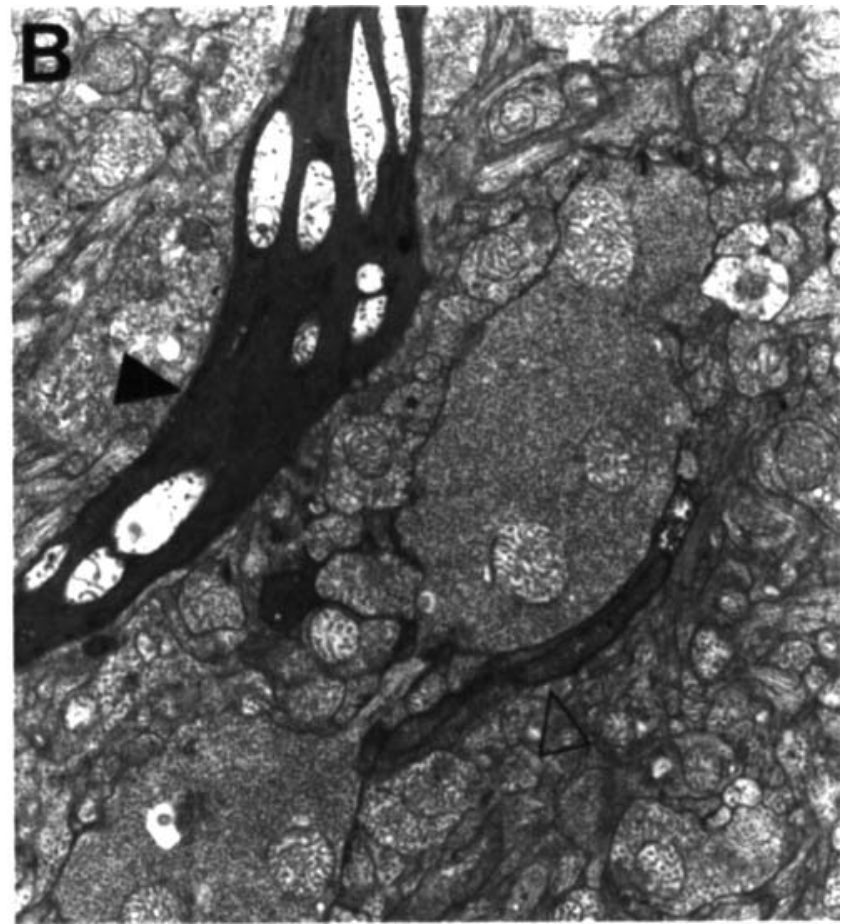

electron dense processes shown in A. Note the pale mitochondria. the uniformly electron dense cytoplasm, and the regularly arrayed microtu. bules in the profile indicated by the filled arrowhead. The open arrowhead indicates an HRP-filled dendrite. Scale bar $=10 \mu \mathrm{m}$ and $2 \mu \mathrm{m}$ in A and $B$, respectively.

intermingled with the bipolar synapses (Freed and Sterling, '88; see also Watanabe et al., '85).

The results from the goldfish and cat are in marked contrast to that reported by Sakai et al. ('86) for large-field ganglion cells in the catfish; synapses near the soma were dispersed along the dendrites, but beyond about $100 \mu \mathrm{m}$ from the soma, groups of 3-7 (amacrine and bipolar) synapses were grouped at discrete sites separated by about $100 \mu \mathrm{m}$ of synapse-free dendrite. Similar to what was seen in the catfish, cells in the goldfish had synapse-free segments of dendrite; however, there were virtually no sites at which the synapses appeared to form discrete clusters. (The one exception, illustrated in the lower right-hand corner of the cell in Fig. 8, was a site where three contacts were made by a single terminal.) The clustering of synaptic contacts onto ganglion cells in the catfish may be related to the fact that the dendrites of these cells are presynaptic to other processes within the IPL. Sakai et al. ('86) showed that at the clusters of input synapses, the dendrites of the large-field ganglion cells formed output synapses. A common feature of neurons with presynaptic dendrites is that the output synapses often form reciprocal connections with the terminals of the input synapses, and together they cluster at discrete sites on the dendritic arbor (e.g., Dowling and Boycott, '66; Hamos et al., '85; Rall et al., '66; Muller and McMahon, '76; Ralston, '71) that are distant or, perhaps, electrically isolated from other clusters of input/output synapses. $\mathrm{Al}$ though Sakai et al. ('86) did not observe any reciprocal synapses, the clustering of input synapses in association with output synapses is a consistent finding. 
Presynaptic specializations were not seen in the dendrites of Type 1.2 cells (see also Marshak et al., '88, who used similar techniques). This difference may be methodological; cells densely filled with the HRP reaction product were selected for in the present study (see also Marshak et al., '88). Sakai et al. ('86) noted that the presynaptic specializations could be seen only in dendrites lightly filled with the HRP reaction product. An obvious caveat is that in the present study any presynaptic specializations may have been obscured, or the disruption of the dendritic cytoplasm by the HRP reaction (see above) may have scattered the vesicles that would be used to identify synaptic contacts. However, the dispersed distribution of synapses onto the dendritic arbor of ganglion cells in the goldfish may serve as circumstantial evidence for the lack of presynaptic dendrites in these cells (see above). Consistent with this, Sakai et al. ('86) found that the synaptic inputs onto small-field ganglion cells in catfish were not clustered, and the dendrites of these cells formed no synaptic outputs.

\section{ACKNOWLEDGMENTS}

The author thanks Drs. D. Marshak and P. Raymond for useful discussions and comments on earlier versions of this paper; A. Ozobia and M. Gillett for technical assistance; and D. Giebel for secretarial assistance. This research was supported by grants BNS 8607886 from the NSF and EY07060 and EY07003 (CORE) from the NIH.

\section{LITERATURE CITED}

Adams, J.C. (1977) Technical considerations on the use of horseradish peroxidase as a neuronal marker. Neurosci. 2:141-145.

Dowling, J.E., and B.B. Boycott (1966) Organization of the primate retina: electron microscopy. Proc. R. Soc. Lond. (B) 166:80-111.

Dubin, M.S. (1970) The inner plexiform layer of the vertebrate retina: A quantitative and comparative electron microscopic analysis. J. Comp. Neurol. 140:479-506.

Famiglietti, E.V., Jr., A. Kaneko, and M. Tachibana (1977) Neuronal architecture of on and off pathways to ganglion cells in carp retina. Science 198:1267-1268.

Freed, M.A., and P. Sterling (1988) The ON-alpha ganglion cell of the cat retina and its presynaptic cell types. J. Neurosci. 8:2303-2320.

Hamos, J.E., S.C. Van Horn, D. Raczkowski, D.J. Uhlrich, and S.M. Sherman
(1985) Synaptic connectivity of a local circuit neurone in lateral geniculate nucleus of the cat. Nature 317:618-621.

Hitchcock, P.F. (1987) Constant dendritic coverage by ganglion cells with growth of the goldfish's retina. Vision Res. 27:17-22.

Hitchcock, P.F., and S.S. Easter, Jr. (1986) Retinal ganglion cells in goldfish: A qualitative classification into four morphological types, and a quantitative study of the development of one of them. J. Neurosci. 6:1037-1050.

Ishida, A.T., W.K. Stell, and D.O. Lightfoot (1980) Rod and cone inputs to bipolar cells in goldfish retina. J. Comp. Neurol. 191:315-335.

Marshak, D.W., M. Ariel, and E. Brown (1988) Distribution of synaptic inputs onto goldfish retinal ganglion cell dendrites. Exp. Eye Res. 46.965978.

Marshak, D.W., T. Yamada, and W.K. Stell (1984) Synaptic contacts of somatostatin-immunoreactive amacrine cells in goldfish retina. J. Comp. Neurol. 225:44-52.

Muller, K.J., and U.J. McMahon (1976) The shapes of sensory and motor neurones and the distribution of their synapses in ganglia of the leech: A study using intracellular injection of horseradish peroxidase. Proc. $\mathrm{R}$. Soc. Lond. (B) 194:481-499.

Muller, J.F., and R.E. Marc (1985) GABA-ergic and glycinergic synapses onto goldfish retinal ganglion cells. Invest. Ophthalmol. Visual Sci. (suppl.) 26:95.

Pickel, V. (1985) General morphological features of peptidergic neurons. In A. Bjorklund and T. Hokfelt (eds.): Handbook of Chemical Neuroanatomy. New York: Elsevier, pp. 72-92.

Rall, W., G.M. Shepherd, T.S. Reese, and M.W. Brightman (1966) Dendrodendritic synaptic pathway for inhibition in the olfactory bulb. Exp. Neurol. 14:44-56.

Ralston, H.J. III (1971) Evidence for presynaptic dendrites and a proposal for their mechanisms of action. Nature 230:585-587.

Sakai, H.M., K.-I. Naka, and J.E. Dowling (1986) Ganglion cell dendrites are presynaptic in catfish retina. Nature 319:495-497.

Vaney, D.I. (1985) The morphology and topographic distribution of A II amacrine cells in the cat retina. Proc. R. Soc. Lond. (B), 224:475-488.

Watanabe, M., Y. Fukuda, C.-F. Hsiao, and H. Ito (1985) Electron microscopic analysis of amacrine and bipolar cell inputs on $\mathrm{Y}-, \mathrm{X}-$, and $\mathrm{W}$-cells in the cat retina. Brain Res. 358:229-240.

West, R.W., and J.E. Dowling (1972) Synapses onto different morphological types of retinal ganglion cells. Science 178:510-512.

Witkovsky, P., and J.E. Dowling (1969) Synaptic relationships in the plexiform layer of carp retina. Z. Zelforsch. 100:60-82.

Wong-Riley, M.T.T. (1974) Synaptic organization of the inner plexiform layer in the retina of the tiger salamander. J. Neurocytol. 3:1-33.

Yazulla, S., J. Mosinger, and C. Zucker (1984) Two types of pyriform Ab amacrine cells in the goldfish retina: an EM analysis of $\left[{ }^{3} \mathrm{H}\right] \mathrm{GABA}$ uptake and somatostatin-like immunoreactivity. Brain Res. 321:352-356.

Yazulla, S., K.M. Studholme, and C.L. Zucker (1985) Synaptic organization of substance P-like immunoreactive amacrine cells in goldfish retina. $J$ Comp. Neurol. 231:232-238. 